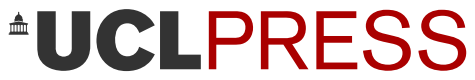

\section{The Journal of the Sylvia Townsend Warner Society}

\section{My Shirt Is in Mexico}

Sylvia Townsend Warner*

How to cite: Warner, S. T. 'My Shirt Is in Mexico.' The Journal of the Sylvia Townsend Warner Society, 2020, 19(1-2), pp. 70-74 • DOI: https://doi.org/10.14324/111.444. stw.2020.11

Published: 15 April 2020

\section{Copyright:}

(C) 2020, Tanya Stobbs. This is an Open Access article distributed under the terms of the Creative Commons Attribution License (CC-BY) 4.0 https://creativecommons.org/licenses/by/4.0/, which permits unrestricted use, distribution and reproduction in any medium, provided the original author and source are credited • DOI: https://doi.org/10.14324/111.444.stw.2020.11

This is a reprint originally published in A Garland of Straw (London: Chatto \& Windus, 1943), pp. 81-4.

\section{Open Access:}

The Journal of the Sylvia Townsend Warner Society is a peer-reviewed open access journal. 


\title{
My Shirt Is in Mexico
}

\author{
Sylvia Townsend Warner
}

\begin{abstract}
Sylvia Townsend Warner lived for nearly half her life in Maiden Newton. Surprisingly, since she was a Communist, and Maiden Newton was a working-class village, she showed little interest in its people. During the Second World War, however, she inevitably became more involved with them. 'Miss Warner' was a driving force in the Women's Voluntary Service in Dorchester, and in Maiden Newton's Civil Defence. Almost all of her short stories about the village date from this chaotic and unpredictable period. They provide a rich source of material about the village's Home Front, and show Warner's attitude to it all: a mix of amusement, pity and resignation which combine to make some very fine stories.
\end{abstract}

Keywords Sylvia Townsend Warner; Valentine Ackland; Maiden Newton; Second World War; Women's Voluntary Service (WVS).

As soon as the train left London, we went along to the buffet car for a drink. The train was crammed, a wartime train loaded with soldiers and with parties of women and children travelling inland to get away from air-raids. It was difficult to move along the corridor; one had to edge one's way past soldiers sitting on their packs, heaps of hand luggage, train-sick children being held out of the window, people queued up sheepishly outside the toilets. But the buffet car was almost empty and looked like something belonging to a different world, with its clean, light-painted walls and red leather upholstery.

We sat down at a little table, and presently the attendant came along with the tariff card. He was a middle-aged man with a good face, innocent 
and humane like a rabbit's. When I said I'd like a cup of black coffee with rum in it, he made no difficulties, though it was not down on the list.

Coming back with our drinks, he looked at us as though we were already friends of his. The rum was in a measuring glass, and as he poured it into my coffee he said: 'Excuse me mentioning it, madam, but I see from your bag you've been in Mexico.'

His voice was full of confidence and excitement. For a moment I wondered if I shouldn't take a chance on it, but I was feeling tired and unsure of my powers, so I said, honestly: 'No such luck. The bag has, but it's only a loan.'

Now we all looked at the label, which was printed with a gay view of flowers and white-clothed tourists riding on festooned mules. And thinking how hard it must be for a man who apparently wanted to go to Mexico to spend his life travelling in a buffet car from Plymouth to London and back again, I said that the friend who owned the bag had liked Mexico very much.

'Oh, yes, it must be a wonderful country,' he said. 'All those hothouse flowers growing wild, and the volcanoes, and the Mexicans making such wonderful artistic things. And everything so old, and yet, in a manner of speaking, only just beginning. Building roads, and learning to read, and getting vaccinated.'

'Sensible beginnings,' said Valentine.

'Yes, that's right. Oh, I'd like to go to Mexico. It must be beautiful... I've got a shirt in Mexico,' he said.

'How did that happen?' I asked. 'You're one up on me. I haven't got anything in Mexico.'

'It's an uncommon thing to say, isn't it? Oil shares, now, or a cousin-that's to be expected. But not a shirt. It all happened before the war, because of a German gentleman, a refugee. I noticed him the moment he came in-he sat down at that table over there-and I thought to myself: Now, he's somebody. A bald man, and thin as a lath, and most remarkably clean. Bald but not elderly, you understand. Presently he ordered a large coffee and a slice of cake. Well, that didn't tell me much, except a nice manner and a German accent. But when I brought along his order, he'd opened his wallet, and there were his papers spread out-a single to Plymouth and a third-class steamer passage.'

\section{'To Mexico?'}

'No, to New York. Well, he didn't say anything I could take hold of. But I'd still got a card up my sleeve-there was the ashtray needed emptying. When I went to change it, he said he didn't smoke. Now, 
I don't smoke either, so that was a beginning. And once you've got a beginning, it's easy, isn't it? From smoking we got round to seasickness, and then I could ask him if he had crossed the Atlantic. "No," said he, "but now I shall." Living in Plymouth, naturally I know a lot about New York, so I could tell him things he'd find useful. Puddings being called desserts, and luggage baggage, and how you can check it through. He laughed, and said he'd be able to carry all his.'

I could see my way to the shirt now.

'Yes, just a suitcase and what he stood up in. What you'd take away for a week-end-and he was going to America for good and all. But not worried in the least. What's more, he seemed so pleased with what he had got. Made me feel his suit to see what good wool it was and told me all about a wonderful pair of silk pyjamas he'd been given. And you could tell from the way he spoke he was the sort of gentleman who knows about clothes-quite a dandy, in fact. He said straight out his shoes were a disappointment to him-they were a gift, too. And he was quite right; they were very poor articles. Then all of a sudden it flashed on me he could have my shirt. It was a very nice shirt. Providential, really-I'd bought it that very morning and was carrying it down with me. I always like to buy my shirts in London. You get a better style. Well, he wasn't the sort of man you can have pretences with, so I told him straight out I'd like him to take my shirt. Wasn't I lucky to have it with me, though?'

'You were,' said Valentine. 'I can't wish anyone better luck than that.'

'Yes, and he accepted it so pleasantly. But what I liked best was the way he opened the parcel and looked at the shirt most carefully-how the buttons were fastened on and all. Examined it all over, he did. If he had just taken the parcel, that wouldn't have been the same thing, would it?'

'And now he's in Mexico?'

'Oh, no. He's in New York. It's the shirt that's in Mexico. With a friend of his. Look, this is the letter he wrote me from New York.'

Often read, always carefully refolded, the thin sheet of paper already had the air of something beginning to be historic:

\section{MARCH 11TH, 1939.}

\section{DEAR FRIEND:}

I have to tell you how I have made good journey and am settled here in New York City. And I have meet other friends here also, and I 
find some work shortly. And the beautiful shirt you gave me, it is not ungratefully that I bestow it to a comrade going to Mexico when he has greater need than I. I do not forget the kindness. I hope you are well and make always new friends. I thank you again.

\section{Cordially,}

RENATUS LEUTNER.

P.S. New York is very fine.

'You must feel happy about that shirt,' I said.

'I do,' he replied. 'It was a blue one, just right for a sunny climate. I've always wanted to go to Mexico.'

A Garland of Straw (London: Chatto \& Windus, 1943), pp. 81-4 
